\title{
On the methylation of inorganic mercury and the decomposition of organo-mercury compounds - a review
}

\author{
Th. M. Lexmond ${ }^{1}$, F. A. M. de Haan ${ }^{1 *}$ and M. J. Frissel ${ }^{2}$ \\ 1 Laboratory of Soils and Fertilizers, Agricultural State University, Wageningen, \\ the Netherlands \\ 2 Association Euratom-ITAL, Wageningen, the Netherlands
}

Accepted: 3 November 1975

Key words: methylation, mercurial decomposition, organomercurial compounds, inorganic mercury, review

\section{Summary}

Mercury is subjected in nature to a number of turnover reactions. The conversion of inorganic to organic forms is governed by microbial methylation which may proceed at aerobic and anaerobic conditions. Decomposition of organic mercurials may follow a chemical or a microbial pathway. The reactions and mechanisms involved, as presented in literature, are described.

\section{Introduction}

Literature on the behaviour of mercury compounds in water, air and soil has become abundant during the last two decades. Most of these papers put main emphasis on the distribution of mercury as affected by human activity. A correct evaluation of human influence, however, requires also information on natural abundances and distribution patterns. As a result, renewed interest in the geochemistry of mercury was shown.

Weathering of mercury-containing rocks, in which the element prevails in the form of mercuric sulphide (cinnabar), released in the course of time an estimated amount of about $1.6 \times 10^{10}$ tonnes (metric tons) of mercury, whereas the release as a result of human activity is estimated at a total amount of $5.0 \times 10^{5}$ tonnes (Gavis \& Ferguson, 1972). Thus at first sight the human contribution seems of minor importance only. It should be realized, however, that the application of mercurycontaining compounds increased very sharply during the last decades. Whereas the present annual contribution of weathering processes is estimated at about 230 tonnes, total production of mercury for industrial application was for 1970 estimated at values ranging from 7000 tonnes (Lagerwerff, 1972) to 10000 tonnes (Gavis \&

* Also guest co-worker of the Institute for Land and Water Management Research (ICW), Wageningen, the Netherlands. 
Ferguson, 1972). Part of this amount is discharged almost directly onto the environment, for example during production procedures or by application as fungicides in agriculture. On the long term, the complete quantity mined will be released into the human environment. (This environment may then be defined as the upper soil layers, the surface water and the atmosphere.) The production figures are to be enlarged with the mercury release as a result of coal and oil burning which may be totalled at about 4600 tonnes per year (Joensuu, 1971; Bertine \& Goldberg, 1971).

Not the total discharge on worldwide basis, however, but much more the distribution pattern and especially the occurrence of high local mercury burdens are of major importance with respect to the incidence of hazardous effects. Calamities as a result of local mercury pollution have been reported. The most dramatic ones concern the 'Minamata disease'. Since 1953 it was noticed that people living around the Minamata Bay, Japan, and feeding themselves primarily with fish and shellfish caught in this bay, suffered from typical neurological disturbances which sometimes led to death or permanent disablement. Only the recently filmed documentary 'Minamata disease, pathology and symptoms' by Noriaki Tsuchimoto (1975; a printed document is also available) shows how difficult it has been for the medical research workers to find out that methyl mercury was the cause. It took them 12 years after the first recorded incidence of the disease to obtain the governmental recognition that mercury-containing waste, which was dumped into the bay by a factory using mercuric chloride as a catalyst in the production of vinyl chloride, was the source of the toxification. At first it was suggested that a conversion to methyl mercury would take place following the discharge of inorganic mercury into the water. Later on it was found that about $1 \%$ of the mercury in the waste water occurred already as methyl mercury, originating as a by-product in the manufacturing of vinyl chloride (Ui, 1969). The officially designated number of patients amounts at present to 800 , about 2700 others are seeking recognition as patients in order to qualify for medical treatment to be paid by the company which released the mercury. One of the most alarming facts is the existence of a retarded form of the 'Minamata disease', indicating that certain types of brain damage become manifest only after many years.

Another well-known result of mercury impact on the environment relates to the reduction of the populations of several bird species as described for Swedish conditions (Katz, 1972). Here it was observed that after 1950 the size of seed-eating, and bird- and rodent-eating bird populations was strongly decreased as a result of high death rate and reduced fertility. It was found that seed dressings with fungicides containing methyl mercury were the main source of these phenomena. Also fisheating birds were found to be diminished. Fish from rivers, lakes and bays in Sweden showed relatively high methyl mercury levels. This seemed to be related to the use of phenyl mercury acetate as a slimicide in pulp and paper industry and to the discharge of inorganic mercury compounds with waste water by chlor-alkali industries. Although it was originally assumed that these mercury species were relatively innocent, it soon became apparent that within the aquatic environment turnover reactions may take place leading to the very toxic methyl mercury compounds.

Thus, the fate of all different mercury species in the environment became of major 
concern. Because of their toxicity the transformations leading to methyl mercury compounds became a point of prime consideration.

\section{Scheme of reactions}

Mercury may occur in three different oxidation states which can be indicated as $\mathrm{Hg}^{\circ}$, elemental mercury, $\mathrm{Hg}_{2}{ }^{2+}$, mercurous ion, and $\mathrm{Hg}^{2+}$, mercuric ion. The distribution of total mercury over each of these oxidation states is governed by conditions like redox potential, $\mathrm{pH}$ and type and abundance of anions or other reactive groups which may induce the formation of thermodynamically stable complexes of mercury. In aerobic surface waters the dominant mercury species are $\mathrm{Hg}(\mathrm{OH})_{2}$ and $\mathrm{HgCl}_{2}$ (Reimers et al., 1974). As a result of stable covalent bonds between mercury and organic carbon, organo-mercury compounds are found (Hem, 1970).

Taking the three oxidation states mentioned above as a point of departure the main mercury transformations occurring in nature can be presented schematically as has been done in Fig. 1. This scheme is an adapted and modified version of the one given by Jernelöv (1969). A brief description of the reactions involved, which will be treated in more detail further on, reads as follows.

1. Both aerobic and anaerobic micro-organisms transform $\mathrm{Hg}^{2+}$ into the more poisonous monomethyl mercury.

2. These micro-organisms can methylate monomethyl mercury to dimethyl mercury. Dimethyl mercury may also directly be formed from $\mathrm{Hg}^{\circ}$ by methane-producing bacteria. Photolytic decomposition of the volatile $\left(\mathrm{CH}_{3}\right)_{2} \mathrm{Hg}$ in the atmosphere results in $\mathrm{Hg}^{\circ}$ and methyl radicals.

3. Anaerobic conditions in nature usually provide sulphide ions, thus allowing the formation of $\mathrm{HgS}$. The extremely low solubility of this compound prevents methylation of mercury at such conditions.

4. Aerobic conditions induce the oxidation of $\mathrm{HgS}$ into the soluble $\mathrm{HgSO}_{4}$, generating again $\mathrm{Hg}^{2+}$ for methylation.

5. At low $\mathrm{pH}$ in the presence of $\mathrm{Hg}^{2+}$ chemical transformation of dimethyl mercury into monomethyl mercury occurs.

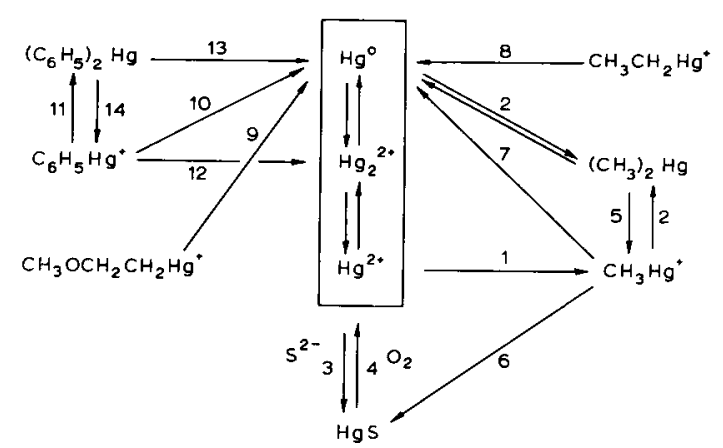

Fig. 1. Schematic presentation of mercury transformations occurring in nature. 
6. After complexation with SH groups of organic matter monomethyl mercury can be decomposed photolytically into methane and $\mathrm{HgS}$.

7. Both aerobic and anaerobic microbes decompose monomethyl mercury into methane and $\mathrm{Hg}^{\circ}$.

$8 / 9 / 10$. In a comparable way as described in Reaction 7 for monomethyl mercury, also ethyl, methoxyethyl and phenyl mercury, respectively, are decomposed resulting in $\mathrm{Hg}^{\circ}$.

11. Microbial turnover of phenyl mercury into diphenyl mercury has been proved. 12. Photolytic decomposition of phenyl mercury into $\mathrm{Hg}_{2}{ }^{2+}$ and phenyl radicals can occur.

13. A similar decomposition is known for diphenyl mercury.

14. At low pH diphenyl mercury is transformed into a benzene nucleus and a phenyl mercury ion; a reaction with $\mathrm{Hg}^{2+}$ at low $\mathrm{pH}$ results in the formation of two phenyl mercury ions (cf. Reaction 5).

\section{Mercury methylation}

\section{Significance of mercury methylation in nature}

Methyl mercury compounds and dimethyl mercury are not as strongly bound to organic matter components as is $\mathrm{Hg}^{2+}$. They are volatile (especially dimethyl mercury), whereas monomethyl mercury is slightly soluble in water. As a result methylation enhances the mobility of mercury. From a quantitative point of view this increased mobility is presumably not so important since the rate of methylation is low. This is confirmed by Swedish observations that lake sediments still contained a considerable amount of mercury 45 years after closing-down of a chlor-alkali industry which used to discharge its waste water on the lake involved (Jernelöv, 1972).

Methylated mercury, however, is easily taken up by living organisms. After uptake it is much more persistent than other organic and inorganic mercury compounds. Thus values for biological half-life (i.e. the time required for $50 \%$ excretion) range from 70 days for man and several fish species, to even 500 days for seals.

Moreover, methyl mercury compounds are much more toxic than other forms of mercury. Their lipophylic character causes an increased mobility in organisms as compared to inorganic mercury. They accumulate particularly in the nervous system and liver of higher animals. Other organic mercury compounds are very unstable in living organisms and decompose to inorganic mercury almost immediately after uptake.

The toxic character of mercury is, at least in part, caused by its interactions with $\mathrm{S}-\mathrm{H}$ and $\mathrm{S}-\mathrm{S}$ bonds of enzymes. This bonding induces a change in the conformation of proteins, resulting in a loss of their enzymic activity and ultimately leading to a serious distortion of the cell metabolism. The high toxicity of dimethyl mercury is attributed to the split-off of a methyl group within the organism, thus introducing the possibility for $\mathrm{Hg}-\mathrm{S}$ interactions.

The uptake of methyl mercury from the aquatic environment by lower organisms 
Table 1. Mercury content $(\mathrm{mg} / \mathrm{kg})$ in water and organisms from Dutch Waddensea (after Fonds, 1971, and Koeman et al., 1971).

\begin{tabular}{lll}
\hline & $\mathrm{Hg}$ total & $\mathrm{CH}_{3} \mathrm{Hg}^{+}$ \\
Water (maximum value) & 0.0002 & \\
Zooplankton & 0.40 & 0.012 \\
Shrimps & 0.12 & 0.067 \\
Herring & 0.18 & 0.09 \\
Sprat & 0.18 & 0.09 \\
Sandsmelt & 0.17 & 0.09 \\
Plaice & 0.21 & 0.12 \\
Flounder & 0.50 & 0.30 \\
Sandwich tern & $0.7-2.6$ & $0.7-2.1$ \\
$\quad$ - liver & 4.9 & \\
$\quad$ - brain & 10.4 & \\
Eider duck & 1.9 & \\
$\quad$ - liver & & \\
- brain & $0.7-31$ & \\
Seals (specimen found dead) & 0.45 & \\
$\quad$ - brain & 28 & \\
- liver (1-day old specimen) & 765 & \\
$\quad$ (full-grown specimen) & \\
\hline
\end{tabular}

and by fish may be directly, or indirectly via food. The formation of methyl mercury after the uptake of inorganic mercury has never been proved for higher organisms. The accumulation via food chains is important as may be shown by Table 1, presenting a survey on mercury contents of water from the Wadden Sea, Netherlands, and of organisms living in this sea. This table constitutes a compilation of data given by Fonds (1971) and by Koeman et al. (1971). It is shown that the accumulation factor is considerably larger for methyl mercury than for total mercury. The methyl mercury content of seals was not determined. It is expected that the major part of mercury occurred in that form.

It has not been proved that methyl mercury found in the organisms from the Wadden Sea originates from the methylation of mercury which finally reaches the Wadden Sea via the river Rhine. Direct discharge of methyl mercury, however, is improbable. As was found for Swedish conditions it seems likely that methylation of inorganic mercury induces the occurrence of methyl mercury in these aquatic organisms at levels which may cause an increased death rate of organisms living at the end of the food chain.

\section{Aerobic mercury methylation}

The occurrence of mercury methylation has first been shown by Jensen \& Jernelöv (1969). After the addition of $100 \mathrm{mg} \mathrm{HgCl}{ }_{2}$ per $\mathrm{kg}$ to sediments from freshwater aquaria, amounts of 180 and $440 \mu \mathrm{g} / \mathrm{kg}$ of mercury as methyl mercury $\left(\mathrm{CH}_{3} \mathrm{Hg}^{+}\right)$ 
were found after incubation periods of 5 and 10 days, respectively. Sterilization of the sediments prior to incubation resulted in a similar amount of methyl mercury as was found in the blancs, viz $40 \mu \mathrm{g} / \mathrm{kg}$. The addition of a small amount of nonsterilized sediment initiated again the formation of methyl mercury, thus indicating a significant role of micro-organisms in the methylation process. Sediments originating from a great number of Swedish lakes, rivers and coastal waters all revealed methylation of $\mathrm{Hg}^{2+}$ at aerobic conditions. An incubation period of 7 days allowed the formation of about $120 \mu \mathrm{g}$ methyl mercury per $\mathrm{kg}$ after addition of $100 \mathrm{mg}$ $\mathrm{HgCl}_{2}$ per kg (Jernelöv, 1969).

Jacobs \& Keeney (1974) collected sediments from the rivers Wisconsin and Fox (USA). Samples were placed back in the river water in polyethylene containers, after pretreatment with various amounts of mercury as $\mathrm{HgCl}_{2}$ and as phenyl mercury acetate. After 12 weeks, a very minor proportion only (a few percents) of the mercury had disappeared thus indicating a strong bonding to the sediments. The sediments of both rivers differed with respect to $\mathrm{pH}$ and organic matter content. While Wisconsin sediment was characterized by low $\mathrm{pH}$ and high organic matter content, Fox sediment was of high $\mathrm{pH}$, low in organic matter but relatively high in sulphide. Wisconsin sediment showed a considerably higher degree of methylation than Fox sediment, viz $200 \mu \mathrm{g} / \mathrm{kg}$ as against $120 \mu \mathrm{g} / \mathrm{kg}$, respectively, starting with $100 \mathrm{mg}$ $\mathrm{HgCl}_{2}$ per $\mathrm{kg}$ (thus indicating the same order of magnitude as found by Jernelöv, 1969). When phenyl mercury acetate was used, a substantial increase of methylation was found, viz $1600 \mu \mathrm{g} / \mathrm{kg}$ for Wisconsin sediments and $370 \mu \mathrm{g} / \mathrm{kg}$ for Fox sediments. Methyl mercury concentrations increased to a maximum value which was arrived at after about 4 weeks. Prolonged continuation of the experiments resulted in constant methyl mercury concentrations, possibly indicating the presence of microbes decomposing methyl mercury.

Langley (1973) studied the methyl mercury uptake in fish living in water of a mercury-contaminated river. Sediments of this river were also placed in the containers. The rate of uptake was found in the range from 0.12 to $4.83 \mathrm{ng} \mathrm{Hg}$ per cm $\mathrm{cm}^{2}$ per week and was influenced by factors like $\mathrm{pH}$, redox potential, microbial activity, mercury concentration, and carbon and nitrogen contents of the sediment.

Beckert et al. (1974) studied the synthesis of methyl mercury compounds in soil starting with mercuric nitrate with radioactive $\mathrm{Hg}^{2+}$. After some time $37 \%$ of total activity was traced back as a compound with the same retention time on thin-layer chromatograms as mono- or dimethyl mercury (a distinction between these two compounds was not possible as a result of the extraction procedure used). The above transformation was not found after sterilization of the soil.

Spangler et al. (1973a) incubated sediments with $\mathrm{HgCl}_{2}$ at aerobic conditions. The sediments originated from the delta of the mercury-contaminated St. Clair river, Michigan (USA). During the first 50 days an increase of the methyl mercury concentration was found up to $310 \mu \mathrm{g} / \mathrm{kg}$. Then a rapid fall of the concentration was measured with a simultaneous formation of elemental mercury.

All observations mentioned point to aerobic methylation. The role of microorganisms in the methylation, as indicated by the inhibition of the process after sterilization, has been investigated by several workers. Methylation of $\mathrm{HgCl}_{2}$ by the 
fungus species Neurospora crassa was described by Landner (1971). Vonk \& Kaars Sypesteyn (1973) studied in this respect a number of bacterium species, viz Pseudomonas fluorescens, Mycobacterium phlë̈, Klebsiella pneumoniae (Aerobacter aerogenes), Bacillus megaterium and Escherichia coli, and several fungi, viz Aspergillus niger, Scopulariopsis brevicaulis and Saccharomyces cerevisiae. All these species were found to be able to form methyl mercury from $\mathrm{HgCl}_{2}$ at aerobic conditions. This indicates that aerobic mercury methylation should be considered as a common property of micro-organisms. The rate of methylation was not species-dependent and of the order of magnitude as described by Jernelöv (1969) and by Jacobs \& Keeney (1974).

The methylation of inorganic mercury has been interpreted as a detoxification mechanism by Landner (1971) and by Wood (1974), in spite of the higher toxicity of methyl mercury when added to a culture of micro-organisms (cf. also Kaars Sypesteyn \& Vonk, 1973). Röntgen irradiation of Neurospora crassa resulted in mutants which could resist much higher mercury levels. At the same time these mutants produced significantly larger amounts of methyl mercury.

\section{Anaerobic mercury methylation}

Two of the bacterium species mentioned are facultatively anaerobic, viz Klebsiella pneumoniae and Escherichia coli. These were found to form methyl mercury also at anaerobic conditions, although the amounts produced were smaller (Kaars Sypesteyn \& Vonk, 1973).

Rissanen et al. (1970) added $\mathrm{Hg}\left(\mathrm{NO}_{3}\right)_{2}$ to anaerobic mud and found no methylation, despite the above mentioned, and probably also other, species of facultatively anaerobic bacteria capable of methylating mercury. Moreover, mud usually contains obligato anaerobic methane-producing bacteria, also capable of performing methylation (Wood et al., 1968; Bishop, 1972).

Yamada \& Tonomura (1972a) isolated an obligate anaerobic spore-producing bacterium species, identified as Clostridium cochlearum. This species produced methyl mercury from $\mathrm{HgCl}_{2}, \mathrm{HgI}_{2}, \mathrm{HgO}, \mathrm{Hg}\left(\mathrm{NO}_{3}\right)_{2}, \mathrm{Hg}(\mathrm{CN})_{2}$ and $\mathrm{Hg}\left(\mathrm{CH}_{3} \mathrm{COO}\right)_{2}$, but not from HgS. Jernelöv (1969) observed methylation inhibition after the addition of excess sulphide ions. The methylation of $\mathrm{HgCl}_{2}$ by Clostridium cochlearum when present in a mixed culture with a sulphate-reducing bacterium was stopped after several hours. This must be ascribed to the removal of $\mathrm{Hg}^{2+}$ by $\mathrm{HgS}$ precipitation as soon as a sufficient $\mathrm{H}_{2} \mathrm{~S}$ production has started.

No methylation could be observed during the fermentation of glucose and corn steep liquor by a mixed culture of methane-producing bacteria. When a low sulphur medium was used by omitting the corn steep liquor and adding excess $\mathrm{Hg}^{2+}$ as $\mathrm{HgCl}_{2}$, methylation was found to take place (Yamada \& Tonomura, 1972c). Methane fermentation requires a redox potential value of about $-400 \mathrm{mV}$. Reduction of sulphur compounds to $\mathrm{H}_{2} \mathrm{~S}$ starts already at a redox potential of $-200 \mathrm{mV}$.

It was shown by Bishop (1972) that similar amounts of methyl mercury were produced in sediment samples of identical composition both at aerobic and anaerobic conditions, provided the absence of $\mathrm{H}_{2} \mathrm{~S}$. 
The obvious conclusion is that methylation of mercury at anaerobic conditions in the presence of $\mathrm{H}_{2} \mathrm{~S}$ (which situation usually prevails in nature) is inhibited not by lack of the relevant micro-organisms, but as a result of the reduced availability of mercury when present as $\mathrm{HgS}$.

$\mathrm{HgS}$ is very slowly methylated in aerobic sediment. In that case, $\mathrm{HgS}$ is first oxidized to the highly soluble $\mathrm{HgSO}_{4}$, thus providing again $\mathrm{Hg}^{2+}$ for methylation (Fagerström \& Jernelöv, 1971, 1972).

\section{The mechanism of methylation}

Three different pathways are available for the transfer of $\mathrm{CH}_{3}$ groups in biological systems:

1. via S-adenosyl methionine; this is a (by means of ATP) activated form of the amino acid methionine, in which the $\mathrm{CH}_{3}$ group is bound to a tertiary sulphonium ion according to

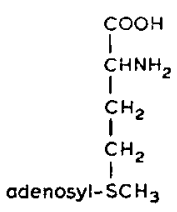

2. via $\mathrm{N}^{5}$-methyl tetrahydrofolic acid and related compounds, in which the $\mathrm{CH}_{3}$ group is bound to a quaternary ammonium ion according to<smiles>C=C(C)N(C)C(C)CNC</smiles>

3. via methyl corrinoids in which the $\mathrm{CH}_{3}$ group is bound to a cobalt ion coordinated by the four nitrogen atoms of a corrin ring, according to

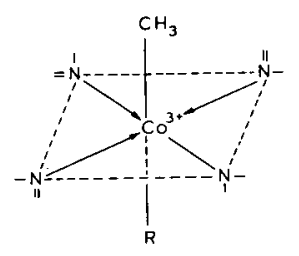

Transfer of a methyl group by S-adenosyl methionine and by $\mathrm{N}^{5}$-methyl tetrahydrofolic acid is in the form of a carbonium ion $\left(\mathrm{CH}_{3}^{+}\right)$. As a result these compounds are unable to methylate the electrophylic $\mathrm{Hg}^{2+}$ ion. Methyl corrinoids may 


\section{REVIEW ON MERCURY BEHAVIOUR}

provide $\mathrm{CH}_{3}$ groups as carbonium ion, but also in the form of a radical $\left(\mathrm{CH}_{3}\right)$ and of a carban ion $\left(\mathrm{CH}_{3}-\right.$ ). Methylation of $\mathrm{Hg}^{2+}$ may thus be performed by the carban ion, methylation of elemental mercury by the radical (Wood \& Brown, 1972).

Methyl pentacyanocobaltate, a complex compound of trivalent cobalt which is used as a model substance for methyl corrinoids may produce methyl mercury after a reaction with $\mathrm{Hg}^{2+}$.

Methyl cobalamin is a methyl corrinoid found in a great number of different species of aerobic and anaerobic micro-organisms. Actually it is a methylated form of vitamin B-12 (cobalamin). The transfer of methyl groups from methyl cobalamin to $\mathrm{Hg}^{2+}$ has been studied by Wood et al. (1968) in extracts of the methane-producing Methanobacterium omelianskii $(\mathrm{MoH})$. In such extracts the methyl cobalamin may serve as a substrate according to the anaerobic reaction

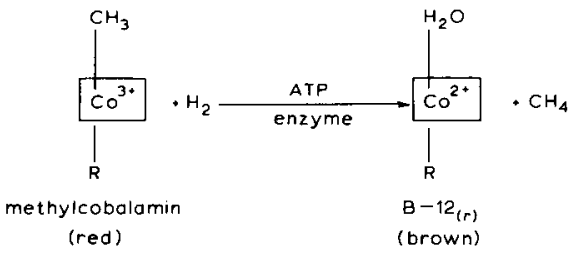

with $\mathrm{R}$ is 5,6-dimethyl benzimidazole. Small additions of $\mathrm{Hg}^{2+}$ strongly inhibited the production of methane whereas the formation of $\mathrm{B}-12(\mathrm{r})$ was not affected. Reaction products could be identified as mono- and dimethyl mercury.

The rapid conversion of methyl cobalamin into $\mathrm{B}-12(\mathrm{r})$ at high $\mathrm{Hg}^{2+}$ concentration levels raised the suggestion that methyl transfer could also proceed via a nonenzymic pathway. (High $\mathrm{Hg}$ levels will block a great deal of SH groups of enzyme proteins, thus deteriorating the enzymic activity as mentioned before.) It was indeed shown that methyl groups could be transferred from $\mathrm{Co}^{3+}$ to $\mathrm{Hg}^{2+}$ at mildly reducing conditions and in the absence of microbial cell extracts. Unfortunately the rates of reaction were not compared for both systems, thus preventing a conclusion on the enzymic character of methylation in the presence of microbial extracts.

Non-enzymic methylation. Non-enzymic methylation of inorganic mercury was also studied by Imura et al. (1971). Reducing conditions appeared not to be a prerequisite. In the presence of a phosphate-buffering solution, mono- and dimethyl mercury were also formed at aerobic conditions from methyl cobalamin and $\mathrm{HgCl}_{2}$. The ratio between the amounts produced of mono- and dimethyl mercury was influenced by the molar ratio of the reacting compounds. At equimolar or smaller amounts of $\mathrm{Hg}^{2}+$ the product mainly consisted of dimethyl mercury, whereas at excess $\mathrm{Hg}^{2+}$ almost exclusively monomethyl mercury was found.

The reaction actually proceeds via an electrophylic attack on methyl cobalamin by the $\mathrm{Hg}^{2+}$ ion. The valency of $\mathrm{Co}^{3+}$ is not changed during the methylation. The reaction is strongly inhibited if mercury is present as $\mathrm{Hg}_{2}{ }^{2+}$ or as $\mathrm{Hg}^{\circ}$, in which forms mercury usually prevails at reducing conditions (Hill et al., 1970).

The rate of methyl transfer from methyl cobalamin to various mercury com- 
pounds was studied by Bertilsson \& Neujahr (1971). They found a rapid methylation of $\mathrm{HgCl}_{2}$ and a much slower one of organic mercury compounds. Thiols and cell extracts acted as inhibitors which must probably be ascribed to a bonding of mercury by the $\mathrm{SH}$ groups of these compounds (proteins in case of cell extracts).

Both $\mathrm{Hg}^{2+}$ and $\mathrm{CH}_{3} \mathrm{Hg}^{+}$are methylated by the cobalamin system. The observation that the rate of $\mathrm{Hg}^{2+}$ methylation exceeds that of $\mathrm{CH}_{3} \mathrm{Hg}^{+}$methylation is in accordance with the suggested mechanism of methyl transfer as a carban ion, the electrophylic character of $\mathrm{Hg}^{2+}$ being much stronger than that of $\mathrm{CH}_{3} \mathrm{Hg}^{+}$. These suppositions were also confirmed by De Simone et al. (1973), who suggested the following reactions for the methylation of $\mathrm{Hg}\left(\mathrm{CH}_{3} \mathrm{COO}\right)_{2}$ and of $\mathrm{CH}_{3} \mathrm{HgCH}_{3} \mathrm{COO}$, respectively:

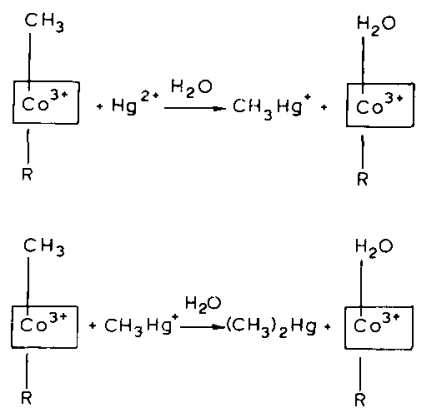

It is fairly hard to evaluate the biological significance of the non-enzymic methylation. As mentioned, methyl cobalamin is usually present in micro-organisms. It may well be that mercury is bound to proteins immediately after entering the microbial cell, thus preventing methylation. It is also possible, however, that the combination of methyl cobalamin with specific proteins from cells exerts a methylating activity which is quite different from the one found in vitro.

Enzymic methylation. A number of different species of micro-organisms, aerobic as well as facultative and obligate anaerobes, contain an enzyme methionine synthetase which plays a role in the synthesis of methionine from homocysteine. Cobalamin constitutes part of this enzyme, thus introducing the possibility that this same enzyme may also catalyse the formation of methyl mercury. Its role in the methionine synthesis may be described according to the reactions:

$$
\mathrm{N}^{s}-\mathrm{CH}_{3}-\mathrm{THF}+\operatorname{cob}(\mathrm{I}) \text { alamin-enzyme } \underset{\begin{array}{c}
\text { reducing } \\
\text { system }
\end{array}}{\stackrel{\text { S-adenosyl- }}{\text { methionine }}} \mathrm{THF}+\text { methylcob(III)alamin- }
$$

enzyme

where THF stands for tetrahydrofolic acid, 
and

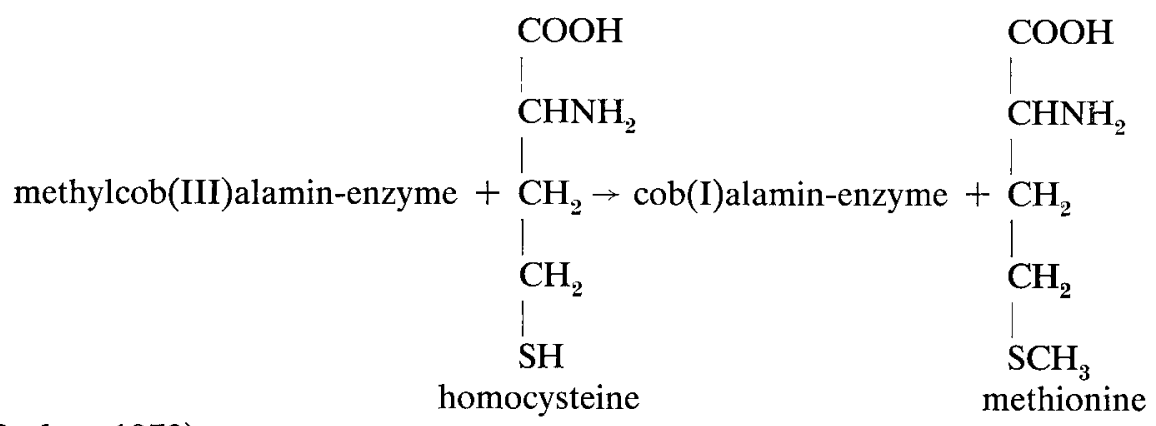

(Barker, 1972)

Methylation of mercury may proceed according to:

methylcob(III)alamin-enzyme $+\mathrm{Hg}^{2+} \rightarrow \mathrm{cob}(\mathrm{III})$ alamin-enzyme $+\mathrm{CH}_{3} \mathrm{Hg}^{+}$

but it seems more probable that the reacting $\mathrm{Hg}^{2+}$ ion is bound to a $\mathrm{SH}$ group, e.g. the one in homocysteine:

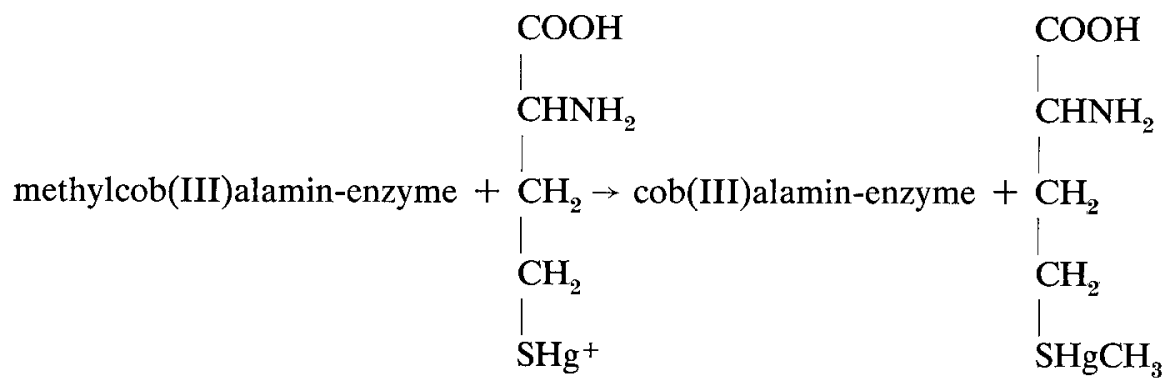

The cob(III)alamin-enzyme complex would be reduced to the cob(I)alamin-enzyme complex, allowing regeneration of methylcob(III)alamin by $\mathrm{N}^{5}-\mathrm{CH}_{3}-\mathrm{THF}$ (reaction a).

Yamada \& Tonomura (1972a, c) described the presence of methyl cobalamin in extracts of the methylating bacterium species Clostridium cochlearum. Increased methylation was found after addition of vitamin B-12, which may serve for synthesis of methylcobalamin according to the above reaction (a). Comparable findings have been reported for Klebsiella pneumoniae by Vonk \& Kaars Sypesteyn (1973).

Wood (1972) developed a hypothesis on the methylation of mercury by methaneproducing bacteria. These bacteria contain relatively large amounts of methyl cobalamin, which plays a role in the methane formation. In Methanobacterium omelianskii $(\mathrm{MoH})$ methyl transfer probably involves a methyl radical $\left(\cdot \mathrm{CH}_{3}\right)$. After the penetration of a $\mathbf{H g}^{2+}$ ion into the cell, the low local redox potential would induce reduction to $\mathrm{Hg}^{\circ}$, finally leading to the formation of dimethyl mercury by uptake of two methyl radicals. Dimethyl mercury may then leave the cell again and be conversed at low $\mathrm{pH}$ in the presence of $\mathrm{Hg}^{2+}$ to monomethyl mercury. An unambiguous proof of this hypothesis has not yet been given. 
Other species have the capacity for mercury methylation although they do not contain methyl cobalamin (e.g. Neurospora crassa and other fungi). It is not clear which other compound than methyl cobalamin can supply sufficiently nucleophilic methyl groups for the methylation. In these species the methylation of homocysteine into methionine proceeds, according to a mechanism which is not well understood but anyway independent of vitamin B-12.

Landner (1971) proposed a biochemical model for the methylation of mercury based upon studies with Neurospora crassa. He found that addition of methionine to a culture of this organism induced growth inhibition at lower $\mathbf{H g}^{2+}$ levels. The addition of homocysteine led to an increased production of methyl mercury. Other thiols did not raise the reaction rate, which makes it highly improbable that this influence should be attributed to an increased $\mathrm{Hg}^{2+}$ uptake as induced by $\mathrm{Hg}^{2+}$ bonding to SH groups. Thus it was concluded by Landner that the transmethylase system of $N$. crassa apparently can methylate the homocysteine- $\mathrm{Hg}^{2+}$ complex. Whereas the common reaction product resulting from homocysteine, i.e. methionine, would exert a feed back control on the transmethylase system, this would not be so with the mercury-containing reaction product. Addition of methionine thus would inhibit the methylation process resulting in an increased toxicity since the organism can no longer remove the $\mathrm{Hg}^{2+}$ ion. This is represented by the following set of equations:

at normal conditions: $\mathrm{COOH}$

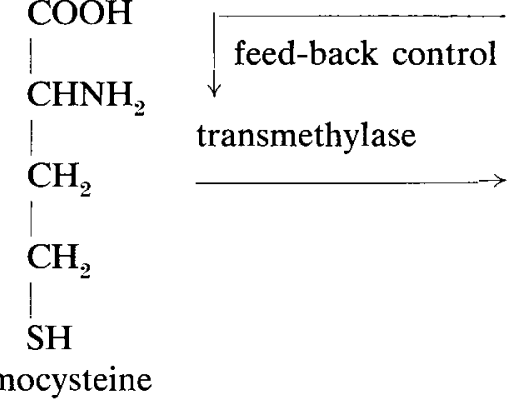

in the presence of $\mathrm{Hg}^{2+}$ : transmethylase

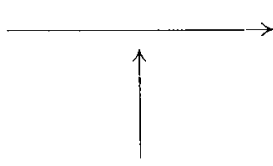

inhibition by methionine

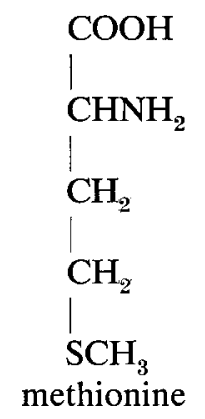

$\mathrm{COOH}$

$\mathrm{CHNH}_{2}$<smiles>[CH]</smiles><smiles>[CH]</smiles>

$\mathrm{SHgCH}_{3}$

homocysteine- $\mathrm{CH}_{3} \mathrm{Hg}^{+}$ complex 
Serious criticism concerning this hypothesis has been made by Vonk \& Kaars Sypestein $(1973,1974)$. They found an increased fungitoxicity of $\mathrm{HgCl}_{2}$ after addition of methionine to cultures of Aspergillus niger, Cladosporium cucumerinum and Scopulariopsis brevicaulis. The effect of methionine on the formation of $\mathrm{CH}_{3} \mathrm{Hg}^{+}$ by $A$.niger was insignificant. It appeared, however, that $A$.niger rapidly demethiolated methionine resulting in the formation of methyl mercaptan. In the presence of $\mathrm{HgCl}_{2}$ mono- and bis-(methylthio)mercury compounds were formed, due to the high affinity of mercury to sulphydryl groups. It was shown that these compounds are more fungitoxic than $\mathrm{HgCl}_{2}$.

\section{Decomposition of organo-mercury compounds}

While methylation of inorganic mercury constitutes a process which is rather commonly met in nature, the formation of other organic mercury compounds has not been shown at natural conditions. Possibly Beckert et al. (1974) observed the synthesis of phenyl mercury in soil. On thin-layer chromatograms they found a minor proportion of ${ }^{203} \mathrm{Hg}$, added to soil as $\mathrm{Hg}\left(\mathrm{NO}_{3}\right)_{2}$, at the phenyl mercury location. This compound, however, was not chemically identified as such.

Application of methyl mercury and other organo-mercury compounds as fungicides in agriculture leads to the introduction of organic mercury in the environment. Awareness of the hazardous effects of mercury has reduced the use of mercurial fungicides. Whereas mercury use in the Netherlands in agriculture and horticulture amounted to 4 tonnes in 1970, this amount decreased to 2 tonnes in 1974 (Frissel \& Poelstra, 1976). Table 2 presents a number of inorganic and organic mercury fungicides and their permissible applications in the Netherlands. General behaviour of such mercury compounds in soil has been discussed by Poelstra et al. (1974), and Frissel \& Poelstra (1976). The attention will be confined here to decomposition reactions of various mercury compounds.

Table 2. Permissible applications of mercury-containing fungicides in the Netherlands.

\begin{tabular}{ll}
\hline Fungicides & Application \\
$\begin{array}{l}\text { Inorganic mercurials } \\
\mathrm{HgCl}_{2}, \mathrm{Hg}_{2} \mathrm{Cl}_{2} \text { and } \mathrm{HgO}\end{array}$ & $\begin{array}{l}\text { disinfection of prune and scamp } \\
\text { injuries and cancer affections of trees } \\
\text { seed dressings of cereals, vegetable } \\
\text { seeds and seeds of cruciferous crops; } \\
\text { treatment of seed potatoes and bulbs }\end{array}$ \\
$\mathrm{CH}_{3} \mathrm{HgX}$ & treatment of seed potatoes \\
Ethyl mercury compounds & \\
$\mathrm{CH}_{3} \mathrm{CH}_{2} \mathrm{HgX}$ & treatment of seed bulbs \\
$\mathrm{Methoxyethyl} \mathrm{mercury} \mathrm{compounds}_{\mathrm{CH}_{3} \mathrm{OCH}} \mathrm{CH}{ }_{2} \mathrm{HgX}$ & \\
Phenyl mercury compounds & disinfection of vegetable seeds and \\
$\mathrm{C}_{6} \mathrm{H}_{5} \mathrm{HgX}$ & treatment of seed bulbs \\
\hline
\end{tabular}




\section{Decomposition of methyl mercury}

This may proceed according to two main pathways, a purely chemical and a microbial one.

Chemical demethylation. In the presence of water, $\mathrm{CH}_{3} \mathrm{Hg}^{+}$invariably occurs as complexes, either with sulphides or thiols, or as hydroxy- or chloride complexes. In the latter case $\mathrm{pH}$ and chloride concentration exert a major influence on the complexation.

In natural conditions methyl mercury will prevail as sulphur complexes. As described by Baughman et al. (1973) these sulphur complexes can be decomposed photochemically according to reactions of the following types:

$$
\begin{array}{lll}
\mathrm{CH}_{3} \mathrm{HgS}- & \mathrm{UV} \text { light } & \mathrm{CH}_{3}+\mathrm{HgS} \\
& \stackrel{\mathrm{UV} \text { light }}{\longrightarrow} & \mathrm{CH}_{3}+\cdot \mathrm{SR}+\mathrm{Hg}^{\circ}
\end{array}
$$

Dimethyl mercury reacts at low $\mathrm{pH}$ with $\mathrm{Hg}^{2+}$ to give methyl mercury, according to:

$$
\left(\mathrm{CH}_{3}\right)_{2} \mathrm{Hg}+\mathrm{Hg}^{2+} \rightleftharpoons 2 \mathrm{CH}_{3} \mathrm{Hg}^{+} \text {(Baughman et al., 1973). }
$$

Along with the above reaction volatile dimethyl mercury readily escapes to the atmosphere. There it is photolysed according to:

$$
\left(\mathrm{CH}_{3}\right)_{2} \mathrm{Hg} \underset{\mathrm{UV} \text { light }}{\longrightarrow} 2 \cdot \mathrm{CH}_{3}+\mathrm{Hg}^{\circ}
$$

The methyl radicals mentioned in these reactions can abstract hydrogen or couple, to give methane and ethane, respectively.

Microbial demethylation. As was mentioned before, aerobic incubation of river sediments with $\mathrm{HgCl}_{2}$ induced an initial increase of the methyl mercury level, followed by a rapid decrease under simultaneous formation of elemental mercury (Spangler et al., 1973a, b). A large number of different bacterium species were isolated from the sediment, a major proportion being able to transform methyl mercury into methane and elemental mercury, both at aerobic and anaerobic conditions. Also Billen et al. (1974) reported aerobic as well as anaerobic decomposition of methyl mercury after methyl mercury addition to sediment of the mercury-contaminated river Sambre (Belgium).

It could be shown that the microbial population is adapted to the methyl mercury level, i.e. those species resistant to methyl mercury survive. Demethylating organisms are resistant and thus will constitute an increasing and finally dominating proportion of the microbial population after mercury pollution. This actually implies an adjustment of the demethylating activity to the contamination level, leading to a steady state situation. Because of interference of synthesis and decomposition reactions it 


\section{REVIEW ON MERCURY BEHAVIOUR}

is impossible to determine the actual methylation rate by measuring the concentration of methyl mercury in a system.

\section{Decomposition of other organo-mercury fungicides}

This may also proceed according to a purely chemical or a microbial process.

Chemical decomposition. Chemical transformation of phenyl mercury compounds was described by Baughman et al. (1973). At low $\mathrm{pH}$ the relevant reaction for diphenyl mercury reads

$$
\left(\mathrm{C}_{6} \mathrm{H}_{5}\right)_{2} \mathrm{Hg}+\mathrm{H}^{+} \rightarrow \mathrm{C}_{6} \mathrm{H}_{5} \mathrm{Hg}^{+}+\mathrm{C}_{6} \mathrm{H}_{6}
$$

A similar reaction describes the decomposition of dimethyl mercury, but the low $\mathrm{pH}$ values involved cause a limitation of the contribution of this reaction in natural systems.

Diphenyl mercury reacts at low $\mathrm{pH}$ with $\mathrm{Hg}^{2+}$, resulting in monophenyl mercury, according to:

$$
\left(\mathrm{C}_{6} \mathrm{H}_{5}\right)_{2} \mathrm{Hg}+\mathrm{Hg}^{2+} \rightleftharpoons 2 \mathrm{C}_{6} \mathrm{H}_{5} \mathrm{Hg}^{+}
$$

Both monophenyl mercury and diphenyl mercury decompose photochemically:

$$
2 \text { monophenyl mercury } \stackrel{\text { UV light }}{\longrightarrow} \mathrm{Hg}_{2}{ }^{2+}+2 \cdot \mathrm{C}_{6} \mathrm{H}_{5}
$$

$$
2 \text { diphenyl mercury } \underset{\mathrm{UV} \text { light }}{\longrightarrow} \mathrm{Hg}^{\circ}+2 \cdot \mathrm{C}_{6} \mathrm{H}_{5}
$$

In a comparable way photochemical decomposition of phenyl mercury hydroxide (which is of importance in aqueous solution) can take place:

$$
2 \text { phenyl mercury hydroxide } \stackrel{\text { UV light }}{\longrightarrow} \mathrm{Hg}^{\circ}+\mathrm{HgO}+2 \mathrm{H}_{2} \mathrm{O}+2 \cdot \mathrm{C}_{6} \mathrm{H}_{5}
$$

The phenyl radicals can abstract hydrogen or couple, to give benzene and diphenyl, respectively.

Microbial decomposition. Kimura \& Miller (1964) studied the decomposition in soil of phenyl mercury acetate, ethyl mercury acetate, methyl mercury dicyanediamide and methyl mercury chloride. Soil treated with phenyl mercury acetate exhibited volatilization of elemental mercury, but not after sterilization. The microbial character of the process involved was also indicated by the enhancing influence of intermediate moisture contents. The use of ethyl mercury acetate resulted in the formation of elemental mercury but in that case also a substantial part of the original mercury compound volatilized. For both methyl mercury compounds mentioned only trace amounts of elemental mercury were detected. Thus it may be concluded that the methyl mercurials are more stable in soil than the other organo-mercury compounds (cf. also the findings on stability in living organisms). 
Nelson et al. (1973) isolated a large number of mercury resistant bacterium species, consisting for about $60 \%$ of pseudomonades. They found phenyl mercury to be decomposed into elemental mercury and benzene.

Matsumura et al. (1971) showed that micro-organisms isolated from lake sediments and from soil conversed phenyl mercury acetate into diphenyl mercury. A number of other metabolites were also formed. These could not exactly be identified, but methyl mercury compounds were not found in these systems.

Direct synthesis of methyl mercury from other organo-mercurials has never been found. As mentioned before, Jacobs \& Keeney (1974) measured a larger methyl mercury production when using phenyl mercury acetate than with $\mathrm{HgCl}_{2}$. This was explained by assuming a different pathway for methyl mercury synthesis from phenyl mercury. It may, however, well be that the lipophylic character of phenyl mercury induces an increased microbial uptake as compared to $\mathrm{HgCl}_{2}$. After decomposition within the cell, the rate of methylation may thus exceed the one for $\mathrm{HgCl}_{2}$.

The carbon-mercury bond in organo-mercurials is broken by microbial influence. This is so for methoxyethyl mercury, phenyl mercury, ethyl mercury and methyl mercury compounds. The result is invariably elemental mercury. This decomposition has been indicated as reductive demercuration.

The mechanism of the reductive demercuration was studied by Furukawa et al. (1969), who used the mercury-resistant species Pseudomonas K62. At aerobic conditions this species opens the carbon-mercury bond in phenyl mercury acetate, ethyl mercury phosphate and methyl mercury chloride under formation of $\mathrm{Hg}^{\circ}$ and the hydrocarbons benzene, ethane and methane, respectively.

The reductive demercuration is schematically presented in Fig. 2, taken from Tonomura et al. (1972). The reaction requires the presence of a number of components (Furukawa \& Tonomura, 1972), which may be listed as:

a) NADH or NADPH (or a system capable to produce these compounds);

b) a metallic mercury releasing enzyme containing FAD as prosthetic group;

c) cytochrome c-I;

d) a sulphur compound; it was found that as such homocysteine and reduced
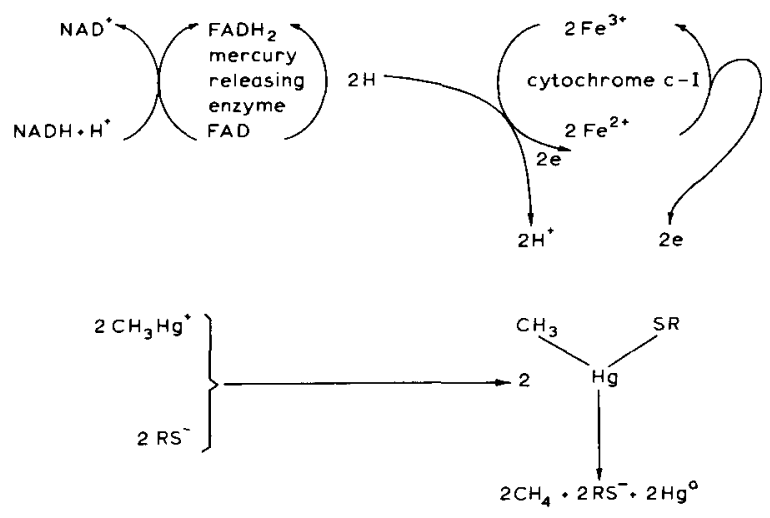

Fig. 2. Reductive demercuration by Pseudomonas K62 (after Tonomura et al., 1972). 


\section{REVIEW ON MERCURY BEHAVIOUR}

glutathion could serve, whereas the oxidized form of these compounds failed. The above system was also capable of reducing $\mathrm{Hg}^{2+}$, added as $\mathrm{HgCl}_{2}$, to $\mathrm{Hg}^{\circ}$. Such a biological reduction has been interpreted by Furukawa et al. (1969) as a detoxification process. Similar conversions have been found in other mercury-resistant bacteria and in mercury-resistant yeast (Komura \& Izaki, 1971; Summers \& Silver, 1972; Summers \& Lewis, 1973; Brunker \& Bott, 1974).

\section{Acknowledgment}

The authors are very much indebted to Dr A. W. S. M. van Egeraat, Department of Microbiology, Agricultural State University, Wageningen, the Netherlands, for valuable criticisms.

\section{References}

Barker, H. A., 1972. Corrinoid-dependent enzymic reactions. A. Rev. Biochem. 41: 55-90.

Baughman, G. L., J. A. Gordon, N. L. Wolfe \& R. G. Zepp, 1973. Chemistry of organomercurials in aquatic systems. Report EPA-660/3-73-012. Washington.

Beckert, W. F., A. A. Moghissi, F. H. F. Au, E. W. Bretthauer \& J. C. McFarlane, 1974. Formation of methylmercury in a terrestrial environment. Nature, Lond. 249: 674-675.

Bertine, K. K. \& E. D. Goldberg, 1971. Fossil fuel combustion and the major sedimentary cycle. Science 173: 233-235.

Bertilsson, L. \& H. Y. Neujahr, 1971. Methylation of mercury compounds by methylcobalamin. Biochemistry 10: 2805-2808.

Billen, G., C. Joiris \& R. Wollast, 1974. A bacterial methylmercury-mineralizing activity in river sediments. Water Res. 8: 219-225.

Bishop, P. L., 1972. Biogenesis of methylmercury in anaerobic pond sediment, University Microfilms, Ann Arbor, Mich. 72-22: 540.

Brunker, R. L. \& T. L. Bott, 1974. Reduction of mercury to the elemental state by a yeast. Appl. Microbiol. 27: 870-873.

De Simone, R. E., M. W. Penley, L. Charbonneau, S. G. Smith, J. M. Wood, H. A. O. Hill, J. M. Pratt, S. Risdale \& R. J. P. Williams, 1973. The kinetics and mechanism of cobalamindependent methyl and ethyl transfer to mercuric ion. Biochim. biophys. Acta 304: 851-863.

Fagerström, T. \& A. Jernelöv, 1971. Formation of methylmercury from pure mercuric sulphide in aerobic organic sediment. Water Res. 5: 121-122.

Fagerström, T. \& A. Jernelöv, 1972. Some aspects of the quantitative ecology of mercury. Water Res. 6: 989-1008.

Fonds, A. W., 1971. Kwik in de Nederlandse oppervlaktewateren. TNO-Nieuws 26: 375-377.

Frissel, M. J. \& P. Poelstra, 1976. Mercury containing fungicides. In: D. Mulder (Ed.), Soil sanitation. Elsevier Scientific Publishing Company, Amsterdam.

Furukawa, K., T. Suzuki \& K. Tonomura, 1969. Decomposition of organic mercurial compounds by mercury-resistant bacteria. Agric. biol. Chem. 33: 128-130.

Furukawa, K. \& K. Tonomura, 1972. Metallic mercury releasing enzyme in mercury-resistant Pseudomonas. Agric. biol. Chem. 36: 217-226.

Gavis, J. \& J. F. Ferguson, 1972. The cycling of mercury through the environment. Water Res. 6: 989-1008.

Hem, J. D., 1970. Chemical behaviour of mercury in aqueous media. In: Mercury in the environment. U.S. Dep. int. Geol. Surv. Prof. Pap. 713: 19-25.

Hill, H. A. O., J. M. Pratt, S. Risdale, F. R. Williamson \& R. J. P. Williams, 1970. Chem. Commun. 124: 341. 
Imura, N., E. Sukegawa, S. Pan, K. Nagao, J. Kim, T. Kwan \& T. Utika, 1971. Chemical methylation of inorganic mercury with methylcobalamin, a vitamin B-12 analog. Science 172: $1248-1249$.

Jacobs, L. W. \& D. R. Keeney, 1974. Methylmercury formation in mercury-treated river sediments during in situ equilibration. J. envir. Qual. 3: 121-126.

Jensen, S. \& A. Jernelöv, 1969. Biological methylation of mercury in aquatic organisms. Nature, Lond. 223: 753-754.

Jernelöv, A. 1969. Conversion of mercury compounds. In: M. W. Miller \& G. G. Berg (Ed.), Chemical fallout. Thomas, Springfield.

Jernelöv, A. 1972. Factors in the transformation of mercury to methylmercury. Environmental Mercury Contamination, Ann. Arbor: 167-177.

Joensuu, O. I., 1971. Fossil fuels as a source of mercury pollution. Science 172: 1027-1028.

Kaars Sypesteyn, A. \& J. W. Vonk, 1973. Methylation of inorganic mercury by bacteria and fungi. Meded. Fak. LandbWet. Gent 38: 759-768.

Katz, A., 1972. Mercury pollution: The making of an environmental crisis. CRC crit. rev. envir. Contr.: 517-534.

Kimura, Y. \& V. L. Miller, 1964. The degradation of organomercury fungicides in soil. J. agric. Fd Chem. 12: 253-257.

Koeman, J. H., J. H. Canton, A. Woudstra, W. H. M. Peeters, J. J. M. de Goey, C. Zeegers \& J. L. van Haaften, 1971. Kwik in het Nederlandse kustmilieu. TNO-Nieuws 26: 402-409.

Komura, I. \& K. Izaki, 1971. Mechanisms of mercuric chloride resistance in microorganisms. I. Vaporization of a mercury compound from mercuric chloride by multiple drug resistant strains of Escherichia coli. J. Biochem. 70: 885-893.

Lagerwerff, J. V., 1972. Lead, mercury and cadmium. In: Micronutrients in agriculture. Soil Science Society of America, Wisconsin.

Landner, L., 1971. Biochemical model for the biological methylation of mercury suggested from methylation studies in vivo with Neurospora crassa. Nature, Lond. 230: 452-454.

Langley, D. G., 1973. Mercury methylation in an aquatic environment. J. Water Pollut. Contr. Fed. 45: 44-51.

Matsumura, F., Y. Gotoh \& G. M. Boush, 1971. Phenylmercuric acetate: metabolic conversion by microorganisms. Science 173: 49-51.

Nelson, J. D., W. Blair, F. E. Brinckman, R. R. Colwell \& W. P. Iverson, 1973. Biodegradation of phenylmercuric acetate by mercury-resistant bacteria. Appl. Microbiol. 26: 321-326.

Poelstra, P., M. J. Frissel, N. van der Klugt \& W. Tap, 1974. Behaviour of mercury compounds in soils: Accumulation and evaporation. In: Comparative studies of food and environmental contamination. International Atomic Energy Agency, Vienna, p. 281-292.

Reimers, R. S., P. A. Krenkel \& A. J. Englande, 1974. Transport and distribution of mercury in sediments. Proc. int. Conf. Transp. persistent Chem. aquatic Ecosyst. (Ottawa) 2: 79-92.

Rissanen, K., J. Erkama \& J. K. Mietinen, 1970. Experiments on microbiological methylation of mercury $(2+)$ ion bij mud and sludge in anaerobic conditions. Conf. marine Pollut. (Rome), FAO-FIR MP/70/E-61.

Spangler, W. J., J. L. Spigarelli, J. M. Rose \& H. M. Miller, 1973a. Methylmercury: bacterial degradation in lake sediments. Science 180: 192-193.

Spangler, W. J., J. L. Spigarelli, J. M. Rose, R. S. Flippin \& H. M. Miller, 1973b. Degradation of methylmercury by bacteria isolated from environmental samples. Appl. Microbiol. 25: 488-493.

Summers, A. O. \& S. Silver, 1972. Mercury resistance in a plasmid-bearing strain of Escherichia coli. J. Bact. 112: 1228-1236.

Summers, A. O. and E. Lewis, 1973. Volatilization of mercuric chloride by mercury resistant plasmid-bearing strains of Escherichia coli, Staphylococcus aureus and Pseudomonas aeruginosa. J. Bact. 113: 1070-1072.

Tonomura, K., K. Furukawa \& M. Yamada, 1972. Microbial conversion of mercury compounds. In: F. Matsumura, G. M. Boush \& T. Misato (Ed.), Environmental toxicology of pesticides. Academic Press, New York. 
Tsuchimoto, Noriaki, 1975. Minamata Disease, a film document by Seirinsha Productions, Tokyo.

Ui, J., 1969. Minamata disease and water pollution bij industrial waste. Rev. int. Océanogr. Med. 23-24: $37-43$

Vonk, J. W. \& A. Kaars Sypesteyn, 1973. Microbial methylation of mercuric chloride. Antonie van Leeuwenhoek 39: 505-513.

Vonk, J. W. \& A. Kaars Sypesteyn, 1974. Increase of fungitoxicity of mercuric chloride by methionine, ethionine and S-methylcysteine. Antonie van Leeuwenhoek 40: 393-400.

Wood, J. M., F. Scott Kennedy \& C. G. Rosen, 1968. Synthesis of methyl-mercury compounds by extracts of methanogenic bacterium. Nature, Lond. 220: 173-174.

Wood, J. M., 1972, cited by B. L. Vallee \& D. D. Ulmer, Biochemical effects of mercury, cadmium and lead. A Rev. Biochem. 41: 91-128.

Wood, J. M. \& D. G. Brown, 1972. The chemistry of vitamin B-12 enzymes. Structure and Bonding 11: 47-105.

Wood, J. M., 1974. Biological cycles for toxic elements in the environment. Science 183: 10491052.

Yamada, M. \& K. Tonomura, 1972a. Formation of methylmercury compounds from inorganic mercury by Clostridium cochlearum. J. Fermentat. Technol. 50: 159-166.

Yamada, M. and K. Tonomura, 1972b. Further study of formation of methylmercury from inorganic mercury by Clostridium cochlearum. J. Ferment. Technol. 50: 893-900.

Yamada, M. and K. Tonomura, 1972c. Microbial methylation of mercury in hydrogen sulfide evolving environments. J. Ferment. Technol. 50: 901-909. 